\title{
Peran Sicantik dalam Meningkatkan Kinerja Perawat di Rumah Sakit
}

\author{
Eka Swedarma, K., ${ }^{1}$ Dwidasmara, IB, ${ }^{2}$ \\ ${ }^{1}$ Prodi Ilmu Keperawatan, Fakultas Kedokteran Universitas Udayana, Bali, Indonesia \\ 2.Prodi Ilmu Komputer, Fakultas MIPA Universitas Udayana, Bali, Indonesia \\ eka.swedarma@unud.ac.id
}

\begin{abstract}
The low ability of nurses in documenting nursing care as a result of limited human resources, too much writing format, differences in perceptions between nurses and the inability of nurses to enforce nursing diagnoses accurately will have an impact on the performance and service delivery to patients. This study aimed to fine out the nurse's performance based on the characteristics of respondents and determine the effect of the application of the Si-Cantik application program (Electronic nursing record system) on the performance of nurses at the hospital. The research method used a one group pre-post test design approach with an intervention in the installation of an electronic nursing record system that is computer-based in the treatment room. The sampling technique used Simple random sampling with sample of 35 nurses. Statistical analysis using Chi-square test and Wilcoxon signed rank test. The results showed that the majority of respondents (77.14\%) found it easy to apply the program, most nurses (77.68\%) had good performance and statistically the implementation of the electronic nursing record system had an effect on nurses' performance in providing nursing care in hospitals $(p=0.004)$. The application of electronic nursing records system can be applied by nurses as supporting nurses' performance in providing nursing care in hospitals and becoming a reference in the use of digital nursing as an effort to develop self-potential so that they can carry out nursing services professionally.
\end{abstract}

Keywords: Nursing documentation, nurse performance, electronic nursing record system

\begin{abstract}
Abstrak
Rendahnya kemampuan perawat dalam mendokumentasikan asuhan keperawatan sebagai dampak dari keterbatasan SDM, format penulisan yang terlalu banyak, perbedaan persepsi antara perawat serta belum mampunya perawat dalam menegakkan diagnosa keperawatan secara akurat akan berdampak terhadap kinerja dan pemberian pelayanan kepada pasien. Penelitian ini bertujuan mengetahui kinerja perawat berdasarkan karakteristik responden dan pengaruh penerapan program aplikasi Si-Cantik (Sistem catatan keperawatan elektronik) terhadap kinerja perawat di Rumah Sakit. Metode penelitian menggunakan pendekatan one group pre-post test design dengan intervensi pemberian instalasi sistem catatan keperawatan elektronik yaitu berbasis komputer pada ruang perawatan. Teknik sampling menggunakan simple random sampling dengan jumlah sampel sebanyak 35 perawat. Analisa statistik menggunakan uji Chi-square dan uji Wilcoxon signed rank test. Hasil menunjukkan bahwa sebagian besar responden $(77,14 \%)$ merasa mudah mengaplikasikan program, sebagian besar perawat $(77,68 \%)$ mempunyai kinerja yang baik dan secara statistik penerapan sistem catatan keperawatan elektronik berpengaruh terhadap kinerja perawat dalam memberikan asuhan keperawatan di Rumah Sakit. ( $\mathrm{p}=0,004)$. Aplikasi sistem catatan keperawatan elektronik dapat diterapkan perawat sebagai penunjang kinerja perawat dalam memberikan asuhan keperawatan di Rumah Sakit dan menjadi referensi dalam pemanfaatan digital nursing sebagai upaya pengembangan potensi diri sehingga bisa melaksanakan pelayanan keperawatan secara profesional.
\end{abstract}

Kata Kunci: Dokumentasi keperawatan, kinerja perawat, sistem catatan keperawatan elektronik

Jurnal Keperawatan Raflesia, Volume 1 Nomor 1, Mei 2019

ISSN: 2656-6222, DOI 10.33088/jkr.vlil.395

Available online: https://jurnal.poltekkes-kemenkes-bengkulu.ac.id/index.php/jkr 


\section{PENDAHULUAN}

Mutu pelayanan rumah sakit sangat ditentukan dari keberhasilan rumah sakit dalam membina sumber daya manusia yang ada. Keberhasilan penyelenggaraan pelayanan di rumah sakit sangat ditentukan oleh kinerja tenaga perawat yang memberikan pelayanan kepada pasien yang dirawat. Karena standar praktik keperawatan pada dasarnya dijadikan sebagai acuan dalam penilaian kualitas pelayanan keperawatan. Permasalahan mengenai kinerja merupakan permasalahan yang akan selalu dihadapi oleh pihak manajemen perusahaan termasuk rumah sakit, salah satunya yaitu terkait dengan bagaimana peran perawat dalam memberikan pelayanan kesehatan dengan melakukan pencatatan atau pendokumentasian asuhan keperawatan tanpa mengabaikan pelayanan kepada pasien sehingga perawat sebagai salah satu penunjang pelayanan kesehatan bisa bersikap secara profesional. Untuk tercapainya suatu asuhan keperawatan profesional diperlukan suatu pendekatan yang disebut proses keperawatan dan dokumentasi keperawatan sebagai data tertulis, yang menjelaskan tentang penyampaian informasi atau komunikasi, yang penerapannya sesuai dengan standar praktik dan pelaksanaan proses keperawatan (Nursalam, 2015).

Dari hasil survei kepuasan pasien yang dilakukan oleh petugas PKRS di ruang rawat inap dengan menggunakan 14 unsur dalam Indeks Kepuasan Masyarakat (IKM) tahun 2012 didapatkan hasil bahwa unsur kecepatan pelayanan hasilnya adalah $79 \%$, kenyamanan lingkungan didapatkan hasil $75 \%$ dan keamanan pelayanan hasilnya adalah $67 \%$ dari standar yang ditetapkan dalam Standar Pelayanan Minimal (SPM) untuk rawat inap adalah $90 \%$. Survei ini menunjukkan bahwa masih banyak pasien atau keluarga pasien yang tidak puas terhadap pelayanan yang diberikan. (RSU Bangli, 2012). Penelitian yang dilakukan oleh Retyaningsih dan Bambang (2013) mengenai kualitas dokumentasi proses asuhan keperawatan, mendapatkan hasil kurang baik dalam kualitas dokumentasi proses asuhan di RSUD dr. Achmad Diponegoro sebesar 54,7\%. Kondisi tersebut disebabkan karena pengetahuan dan pemahaman perawat yang kurang. Selain itu faktor waktu atau lama pelaksanaan pendokumentasian yang dibutuhkan perawat mempunyai pengaruh yang signifikan dalam kelengkapan dokumentasi asuhan keperawatan. Faktor penghambat yang dihadapi perawat dalam mendokumentasikan asuhan keperawatan yaitu tidak seimbangnya jumlah tenaga kerja perawat dengan pekerjaan yang ada, selain itu dokumentasi keperawatan dipengaruhi oleh beberapa faktor lain yaitu umur, jenis kelamin, tingkat pendidikan, pendapatan, beban kerja, masa kerja, waktu/lama pelaksanaan, lingkungan kerja.

$\begin{aligned} & \text { Pelaksanaan } \\ & \text { keperawatan } \\ & \text { dilaksanakan berdasarkan aturan atau } \\ & \text { standar yang sudah ditetapkan serta }\end{aligned}$
maksimal data harus diisi berdasarkan
fakta (factual basis), akurat (accuracy),
lengkap (completeness), ringkas
(conciseness), terorganisir (organization),
waktu yang tepat (time liness), dan bersifat
mudah dibaca (legability) (Potter \& Perry,
2009).

Kemajuan teknologi informasi semakin pesat dan sudah banyak aplikasi yang mengarah ke ranah medis, seperti Sistem 
Informasi Manajemen Rumah Sakit, Sistem Pakar untuk Diagnosa Kedokteran, Sistem Pendukung Keputusan, Embedded System untuk alat-alat medis seperti Digital Laboratorium, USG, dan lain sebagainya. Dari beberapa permasalahan pendokumentasian keperawatan seperti tingkat pengetahuan pada pendokumentasian masih kurang, hal ini dapat diatasi dengan pendekatan pemaanfaatan teknologi informasi untuk mempermudah perawat dalam melakukan kegiatan pendokumentasian asuhan keperawatan dan mengurangi perbedaan persepsi diantara perawat. Dengan demikian hal tersebut dapat mengoptimalkan kinerja perawat menuju layanan prima di rumah sakit melalui penerapan dokumentasi asuhan keperawatan berbasis komputer.

Berdasarkan hasil studi pendahuluan melalui wawancara dengan beberapa orang perawat pelaksana di RSU Bangli bulan Juli 2016, ada beberapa faktor yang menyebabkan kurangnya pendokumentasian proses keperawatan antara lain: kurangnya motivasi individu perawat untuk menulis, belum adanya kesamaan persepsi terhadap penegakan diagnosa keperawatan, belum mampunya mengambil keputusan terkait dengan penegakan diagnosa keperawatan, jumlah pasien yang dirawat terlalu banyak, jumlah tenaga perawat tidak sebanding dengan jumlah pasien, blangko terlalu menjelimet dan terbatas, waktu, umpan balik dan penerapan komunikasi therapeutik terhadap masing-masing individu pasien masih kurang, tingkat pengetahuan pada pendokumentasian masih kurang. Sementara di RSU Bangli sebagian besar perawat di Ruang Rawat Inap merasa tidak bisa memberikan pelayanan secara maksimal kepada pasien karena keterbatasan SDM, terlalu banyak format laporan yang harus di tulis sehingga lama kontak ke pasien relatif singkat. Upaya yang sudah dilakukan yaitu dengan mensederhanakan format pendokumentasian keperawatan namun hal tersebut belum memberikan perkembangan yang berarti, ada perawat yang masih belum mau menuliskan laporannya secara lengkap dalam format dokumentasi yang disediakan sehingga kondisi ini tentu akan mempengaruhi aspek legal etik dalam keperawatan.

Beberapa kajian tentang dokumentasi asuhan keperawatan secara elektronik yang serupa sudah pernah dilakukan namun hanya sebatas literatur review seperti yang dilakukan oleh Sulastri dan Sari (2018) dengan judul "Metode Pendokumentasian Elektronik dalam Meningkatkan Kualitas Pelayanan Keperawatan" dan Khanifatuzzahro dan Kurniadi (2015) dengan judul "Rancangan Sistem Informasi Pencatatan Asuhan Keperawatan Berbasis Elektronik di RSUD Kota Semarang" yaitu studi deskriptif dengan metode SDLC (System Development Life Cycle) menguji sistem hanya pada satu perawat dan satu kepala ruang. Perbedaan dengan penelitian ini yaitu pada penelitian ini menggunakan rancangan bangun sistem dengan metode Foward Chaining berbasis Nanda, NIC, NOC selanjutnya dilakukan uji sistem serta penilaian kinerja perawat di Rumah Sakit.

\section{METODE}

Penelitian ini menggunakan metodologi one group pre-post test design dengan intervensi pemberian instalasi sistem catatan keperawatan elektronik dalam 
bentuk dokumentasi asuhan keperawatan pada komputer ruangan perawat. Penelitian dilakukan untuk mengetahui tingkat akurasi sistem catatan keperawatan elektronik dengan uji algoritma, kebutuhan formal informal sistem melalui uji persepsi perawat dengan kuisioner, serta membandingkan kinerja perawat ditinjau dari segi pengetahuan, sikap tindakan keperawatan dan pendokumentasian asuhan keperawatan sebelum dan setelah diberikan aplikasi program tersebut dengan menggunakan kuisioner. Evaluasi kinerja dilakukan setelah 2 bulan penggunaan aplikasi program tersebut.

Aplikasi yang dibangun adalah Sistem catatan keperawatan elektronik atau dokumentasi asuhan keperawatan berbasis komputer. Aplikasi akan membantu perawat dalam pengkajian keperawatan, mengambil keputusan penegakan diagnosa keperawatan, intervensi keperawatan, implementasi keperawatan, evaluasi keperawatan serta mendokumentasikan asuhan keperawatan yang telah dilaksanakan.

Aplikasi dibuat berbasis komputer agar aplikasi dapat digunakan kapan saja dan dimana saja sebagai pengganti buku yang memiliki kemampuan tambahan sistem pendukung keputusan yang dapat digunakan secara mudah, cepat dan akurat. Pengembangan Sistem menggunakan Metode SDLC (System Depelopment Life Cycle), meliputi: Analisis Kebutuhan Sistem: ini merupakan tahap awal dalam pengembangan sistem, dimana untuk membuat aplikasi ini dibutukan informasi tentang data-data yang diolah dan ditampilkan pada sistem, informasi yang berguna bagi pengguna.

Sistem yang telah dirancang akan diimplementasikan menjadi sebuah sistem nyata. Sistem akan dibuat dalam bentuk aplikasi agar dapat digunakan pada komputer dimana saja dan kapan saja, dengan menerapkan teknologi untuk mengolah data dan menyajikan informasi yang dibutuhkan. Dataset akan disimpan di dalam lokal basis data perangkat komputer dan dataset dapat diperbaharui melalui pembaharuan dataset yang dapat diunduh dari server yang telah disediakan dengan berbasis $M y S Q L$ yang merupakan freeware yang sangat popular. Kebutuhan resource bagi MySQL tidaklah besar, walupun demikian kemampuan keamanannya sangat bisa dihandalkan. MySQL juga mampu menangani data bervolume besar (Suja, 2011).

Populasi penelitian ini adalah perawat yang bertugas di Rumah Sakit Umum Bangli dengan jumlah sampel sebanyak 35 perawat dengan teknik simple random sampling. Uji akurasi aplikasi model menggunakan uji algoritma, kebutuhan formal/non formal berdasarkan persepsi perawat terhadap aplikasi sistem catatan keperawatan elektronik, analisis menggunakan uji chi-square untuk mengetahui kinerja perawat berdasarkan karakteristik responden serta Wilcoxon signed rank test untuk mengetahui pengaruh penerapan sistem catatan keperawatan elektronik berbasis komputer terhadap kinerja perawat. 


\section{HASIL}

Tabel 1. Persepsi Penerapan Aplikasi Sicantik Berdasarkan Variabel Sosiodemografi

\begin{tabular}{|c|c|c|c|}
\hline \multirow[t]{2}{*}{$\begin{array}{c}\text { Variabel } \\
\text { Sosio-demografi }\end{array}$} & \multirow[t]{2}{*}{$\mathrm{n}(\%)$} & \multicolumn{2}{|c|}{$\begin{array}{l}\text { Persepsi penerapan aplikasi catatan } \\
\text { keperawatan elektronik berbasis kompute }\end{array}$} \\
\hline & & Mudah (\%) & Sulit (\%) \\
\hline \multicolumn{4}{|l|}{ Jenis Kelamin } \\
\hline Laki-laki & $11(31,4)$ & $9(81,8)$ & $2(18,2)$ \\
\hline Perempuan & $24(68,6)$ & $18(75)$ & $6(25)$ \\
\hline \multicolumn{4}{|l|}{ Tingkat Pendidikan } \\
\hline DIII Keperawatan & $15(42,8)$ & $10(66,6)$ & $5(33,4)$ \\
\hline S1 Ners & $20(57,2)$ & $17(85,0)$ & $3(15,0)$ \\
\hline \multicolumn{4}{|l|}{ Status perkawinan } \\
\hline Kawin & $23(65,7)$ & $17(73,9)$ & $6(26,1)$ \\
\hline Tidak Kawin & $12(34,3)$ & $10(83,3)$ & $2(16,7)$ \\
\hline \multicolumn{4}{|l|}{ Status kepegawaian } \\
\hline PNS & $20(57,2)$ & $17(85,0)$ & $3(15,0)$ \\
\hline Honorer/ kontrak & $15(42,8)$ & $10(66,6)$ & $5(33,4)$ \\
\hline \multicolumn{4}{|l|}{ Masa kerja } \\
\hline$<5$ Tahun & $12(34,3)$ & $10(83,3)$ & $2(16,7)$ \\
\hline$>5$ Tahun & $23(65,7)$ & $17(73,9)$ & $6(26,1)$ \\
\hline
\end{tabular}

Berdasarkan tabel 1. dapat dijelaskan bahwa dari 35 orang sebanyak 27 orang $(77,14 \%)$ merasa mudah untuk mengaplikasikan metode catatan keperawatan elektronik: laki-laki $(81,8 \%)$ sedangkan yang perempuan (75\%).
Ditinjau dari tingkat pendidikan persepsi perawat sebagian besar menyatakan mudah pada tingkat pendidikan S1 Ners (85\%), dengan status tidak kawin $(83,3 \%)$, PNS $(85 \%)$ dan masa kerja $<$ dari 5 tahun sebanyak $(83,3 \%)$.

Tabel 2. Kinerja Perawat dalam Melaksanakan Asuhan Keperawatan Berdasarkan Sosiodemografi Responden

\begin{tabular}{|c|c|c|c|c|c|}
\hline \multicolumn{6}{|c|}{ Kinerja Perawat dalam Asuhan Keperawatan } \\
\hline Variabel & $\begin{array}{c}\text { Baik } \\
\text { n }(\%)\end{array}$ & $\begin{array}{c}\text { Kurang } \\
\mathrm{n}(\%)\end{array}$ & $\begin{array}{l}\text { Odd Ratio } \\
\text { (OR) }\end{array}$ & $(95 \% \mathrm{CI})$ & P Value \\
\hline \multicolumn{6}{|l|}{ Pendidikan } \\
\hline Diploma & $11(72,61)$ & $4(27,39)$ & 2,662 & $(1,985-8,022)$ & $0,008^{*}$ \\
\hline Sarjana & $17(85,85)$ & $3(14,15)$ & Ref. & & \\
\hline \multicolumn{6}{|l|}{ Status perkawinan } \\
\hline Tidak kawin & $10(83,05)$ & $2(16,95)$ & 0,517 & $(0,212-1,261)$ & 0,174 \\
\hline Kawin & $18(78,82)$ & $5(21,18)$ & Ref. & & \\
\hline \multicolumn{6}{|c|}{ Status kepegawaian } \\
\hline PNS & $16(80,00)$ & $4(20,00)$ & Ref. & & \\
\hline Honorer/Kontrak & $12(80,00)$ & $3(20,00)$ & 3,511 & $(2,023-25,510)$ & $0,011 *$ \\
\hline \multicolumn{6}{|l|}{ Jenis Kelamin } \\
\hline Laki-laki & $9(81,05)$ & $2(18,95)$ & Ref. & $(2,814-22,744)$ & 0,320 \\
\hline Perempuan & $19(78,82)$ & $5(21,18)$ & 8,002 & & \\
\hline \multicolumn{6}{|l|}{ Masa kerja } \\
\hline$<5$ tahun & $10(83,05)$ & $2(16,95)$ & Ref. & $(8,152-79,098)$ & $0,000 *$ \\
\hline$>5$ tahun & $18(78,82)$ & $5(21,18)$ & 5,393 & & \\
\hline
\end{tabular}

*bermakna pada $\alpha=0,05$ 
Dalam hal ini perawat hendaknya dapat melakukan tugas dan tanggung jawabnya sesuai yang telah ditetapkan organisasi. Kinerja itu sendiri dapat merupakan penampilan individu maupun kelompok kerja personel. Penampilan hasil kerja tidak terbatas kepada personel yang memangku jabatan fungsional maupun struktural tetapi juga pada keseluruhan jajaran personel di dalam organisasi.

Pencapaian standar asuhan keperawatan yang maksimal, dokumentasi keperawatan harus diisi dengan data yang lengkap dan valid. Tetapi pada kenyataannya seringkali perawat sibuk dengan pendokumentasian sehingga menghabiskan banyak waktu dan melupakan tugas utama menjadi seorang perawat yaitu memberikan asuhan keperawatan kepada klien yang sedang dirawat. Kesibukan perawat dalam menulis asuhan keperawatan membuat waktu yang seharusnya digunakan untuk merawat klien menjadi berkurang sehingga nantinya berdampak kepada klien baik terhadap kesembuhannya ataupun komplikasi yang mungkin timbul saat perawatan sehingga metode komputerisasi bisa dimanfaatkan sebagai sistem pendukung kinerja perawat dalam melaksanakan asuhan keperawatan serta sebagai bukti dokumentasi atau evidence based secara klinis tentang kondisi kesehatan klien.

Penggunaan dokumentasi berbasis bukti dapat meningkatkan kepemimpinan institusional dalam dokumentasi klinis. Adapun faktor kunci dari keberhasilan yaitu hubungan kolaborasi yang efektif antara perawat dengan staf teknologi informasi, dukungan dari pimpinan keperawatan, sumber daya ahli serta motivasi yang kuat terhadap pelaksanaan program tersebut (Klehr, J. et.al, 2009).
Berdasarkan hasil penelitian menunjukkan bahwa secara umum sebagian besar perawat $(77,14 \%)$ dapat memahami serta mampu secara mudah mengaplikasikan catatan keperawatan elektronik berbasis komputer di Rumah sakit. Kondisi ini juga diperkuat dengan hasil uji kebutuhan non fungsional dengan nilai akurasi $(82,85 \%)$ sehingga program aplikasi tersebut cukup layak untuk diterapkan di Rumah Sakit. Sedangkan Uji statistik menunjukkan bahwa nilai $\mathrm{p}=0,004$ yang berarti bahwa sistem catatan keperawatan elektronik berpengaruh terhadap kinerja perawat dalam memberikan asuhan keperawatan di Rumah Sakit.

Hasil penelitian ini relevan dengan penelitian yang dilakukan Maufiroh, Shintia \& Lestari (2015) mengenai gambaran persepsi perawat terhadap efektivitas penggunaan electronic nursing record (ENR) sebagai inovasi dokumentasi asuhan keperawatan Rumah Sakit Umum Bunda Jakarta menunjukkan persepsi positif pada tampilan sistem $(56,77 \%)$, persepsi kemudahan $(77,4 \%)$ dan persepsi kebermanfaatan $\quad(98,8 \%)$ Perawat menunjukkan persepsi positif terhadap penggunaan ENR. Hal ini juga sejalan dengan penelitian yang dilakukan Menachemi \& Collum (2011) menjelaskan tentang manfaat penerapan electronic nursing record yaitu menghasilkan catatan yang akurat, jelas, lengkap, serta mengurangi duplikasi data dan workload perawat dalam melakukan dokumentasi.

Penerapan electro nursing record di Amerika Serikat dapat diakses secara terpusat/nasional sehingga informasi riwayat kesehatan dapat diakses melalui jalur komputer. Perawat secara mudah dapat mengaplikasikan program tersebut 
sehingga dapat memberikan pelayanan kesehatan secara berkualitas melalui nursing informatics, yang merupakan inti/forefront dari dokumentasi keperawatan berbasis komputer (Mitchel, et.al, 2009)

Pencatatan berbasis elektronik atau komputer merupakan sistem pendukung dalam pendokumentasian asuhan Keperawatan. Metode komputasi forward chaining penegakan diagnosa keperawatan dalam catatan keperawatan elektronik dipercaya dapat mendukung kualitas pendokumentasian asuhan keperawatan, meningkatkan kinerja dan mengurangi beban kerja perawat dalam melaksanakan asuhan keperawatan. Keuntungan peralihan dari paper-based ke catatan keperawatan elektronik yaitu mengurangi biaya penggunaan kertas, tidak memerlukan gudang yang besar dalam penyimpanan data/arsip, penyimpanan data klien menjadi lebih lama, mengurangi pencatatan yang berulang, mengurangi kesalahan dalam menginterprestasikan pencatatan, meningkatkan kualitas informasi dan meningkatkan waktu perawat berfokus pada pemberian asuhan Keperawatan.

Adanya pengalaman perawat serta kebiasaan perawat dalam memanfaatkan perkembangan teknologi informasi sangat berdampak terhadap kegiatan keseharian perawat dalam memberikan asuhan keperawatan. Pemanfaatan mobile phone secara tepat guna sebagai sarana komunikasi juga memberikan suatu dampak yang positif terhadap perawat terutama dalam mengidentifikasi fitur-fitur yang ada sehingga lebih mudah untuk memahami aplikasi program komputer. Kondisi ini sangat relevan dengan hasil penelitian yang didapatkan bahwa semakin tinggi pendidikan semakin baik dalam mengaplikasikan tekhnologi informasi yang ada.

Pengoperasian catatan keperawatan elektronik (Sicantik) terbilang relatif mudah, namun terdapat beberapa kendala yaitu pembuatan program yang cukup lama sehingga belum semua komponen dalam Nursing Interventions Classification (NIC), dan Nursing Outcomes Classification (NOC) terinput dalam program tersebut. Pendokumentasian asuhan keperawatan merupakan suatu hal yang sangat penting. Apabila hal ini kurang mendapatkan perhatian dan dibiarkan tanpa adanya penanganan secara tepat dikhawatirkan akan berdampak terhadap peningkatan kualitas mutu pelayanan rumah sakit.

\section{KESIMPULAN}

Sebagian besar perawat merasa mudah untuk mengaplikasikan catatan keperawatan elektronik. Pendidikan, status kepegawaian dan masa kerja merupakan faktor dominan yang berhubungan dengan kinerja perawat, sebagian besar perawat mempunyai kinerja yang baik dalam melaksanakan asuhan keperawatan di Rumah Sakit dan penerapan sistem catatan keperawatan elektronik berpengaruh terhadap kinerja perawat di Rumah Sakit. Oleh karena itu program aplikasi ini dapat dimanfaatkan bagi Rumah Sakit sehingga perawat bisa belajar dengan baik sebagai upaya pengembangan potensi diri dalam melaksanakan pelayanan keperawatan secara profesional. Hasil Penelitian ini selanjutnya dapat direplikasi dan dikembangkan dalam bentuk software pada smart phone untuk menunjang 
kinerja perawat khususnya memberikan asuhan keperawatan kepada pasien/klien di Rumah Sakit serta menyongsong pada era digital 4.0.

\section{DAFTAR PUSTAKA}

Depkes, RI. (2012). Standar tenaga keperawatan di rumah sakit. Jakarta: Depkes RI.

Hasibuan, Melayu SP. (2011). Manajemen sumber daya manusia. Edisi Revisi Jakarta: Bumi Aksara.

Khanifatuzzahro, L., \& Kurniadi, A. (2015). Rancangan sistem informasi pencatatan asuhan keperawatan berbasis elektronik di RSUD kota semarang tahun 2015. Di unduh dari http://eprints.dinus.ac.id/17371/1/jurnal _15965.pdf.

Klehr, J., Hfner, J., Spelz, L. M., Steen, S., \& Weaver, K., (2009). Implementation of standardized nomenclature in the electronic medical record. International Journal of Nursing Terminologies and Classifications, (20)4, doi: 10.1111.

Kurniadi, A. (2011). Pemrograman microsoft visual basic 6. Jakarta: PT Elex Media Komputindo.

Maufiroh, Shintia, Silvana, Pipit Lestari, (2015). Gambaran persepsi perawat terhadap efektivitas penggunaan electronic nursing record sebagai inovasi dokumentasi asuhan keperawatan di rumah sakit umum bunda jakarta. Bimiki, 3(2). Diunduh dari

https://issuu.com/bimkes/docs/bimiki_v ol_3_no_2.

Menachemi, N., \& Collum, T. H. (2011). Benefits and drawbacks of electronic health record systems. Risk Management and Healthcare Policy, 4, 47-55. http://doi.org/10.2147/RMHP.S12985.
Mitchel, B., Petrovskaya, O., Mclntyre, M. \& Frisch, N. (2009). Where is nursing in the electronic health care record?. Study Health Technol Inform, 143:202-6.

NANDA. (2015). Nursing diagnoses: Definitions \& classification 2015-2017. Philadelphia: NANDA International.

Nursalam. (2015). Manajemen keperawatan aplikasi dalam praktik keperawatan profesional. (Edisi ke-3). Jakarta: Salemba Medika.

Potter, P. A, \& Perry, A. G. (2009). Buku ajar fundamental keperawatan: Konsep, proses, dan praktik. (Edisi ke-4). Alih Bahasa: Renata Komalasari, dkk. Jakarta: EGC.

Retyaningsih, I. D. \& Bambang, E.W. (2013). Hubungan karakteristik perawat, motivasi, dan supervisi dengan kualitas dokumentasi proses asuhan keperawatan. Jurnal Managemen Keperawatan, 1(2). 107-114.

RSU Bangli. (2012). Laporan Tahunan Rumah Sakit Umum Bangli. Bali: Bangli.

Sulastri, \& Sari, N. Y. (2018). Metode pendokumentasian elektronik dalam meningkatkan kualitas pelayanan keperawatan. Jurnal Kesehatan, 9(3), http://ejurnal.poltekkestjk.ac.id/index.ph $\mathrm{p} / \mathrm{JK}$.

Suja, I. (2011). Pemrograman SQL dan database server MySQL. Yogyakarta: Andi.

Wibowo. (2012). Manajemen kinerja. Jakarta: PT Raja Grafindo Persada. 


\section{HALAMAN INI SENGAJA DIKOSONGKAN}

